\title{
LANDSCAPE
PERFORMANCE
SERIES
}

\section{Loyola University Lake Shore Campus Methods Document}

Prepared by:

Research Fellow: M. Elen Deming, Professor, University of Illinois

Research Assistant: D. Scott Douglas, MLA Candidate, University of Illinois

Firm Liaison: Patrick Brawley, Principal, SmithGroupJJR

This Methods Document accompanies a Landscape Performance Series Case Study Brief. It was produced through the Landscape Architecture Foundation's Case Study Investigation (CSI) 2015 program, a unique research collaboration that matches LAFfunded faculty-student research teams with leading practitioners to document the benefits of exemplary high-performing landscape projects.

The full case study can be found at:

https://landscapeperformance.org/case-study-briefs/loyola-university 


\section{Landscape Performance Benefits}

\section{Environmental Benefits:}

1. Captures and infiltrates $22 \%$ of total stormwater runoff through the use of underground infiltration trenches and storage vaults.

The combined sewer system in the city of Chicago is overburdened and is prone to combined sewer overflow events (CSO) during periods of heavy rainfall. A review of confirmed CSO events found the following number of CSO event occurrences:

2011: 38 confirmed CSO events

2012: 21 confirmed CSO events

2013: 41 confirmed CSO events

2014: 41 confirmed CSO events

2015: 16 confirmed CSO events (as of 7/13/2015)

In an effort to reduce the university campus' stormwater contribution to the City of Chicago's combined sewer system, the university has begun treating stormwater on the campus. This has been fulfilled by the utilization of on-site filtration systems (which discharge clean water directly into Lake Michigan), the use of permeable paving, and the installation of 1.2 acres of green roofs on campus buildings.

Method

Existing conditions:

Drainage area: 29.09 acres

Runoff Coefficient: 0.71

Peak Discharge: 189.15 cfs

Total Runoff: $\quad 208,251 \mathrm{cf}$

Design conditions:

Drainage area: 29.09 acres

Runoff Coefficient: 0.68 (slight reduction due to reduction of impervious surfaces)

Peak Discharge: $181.15 \mathrm{cfs}$ 
Total Runoff: $\quad 199,451 \mathrm{cf}$

The redesign of the campus results in a reduction of $8,800 \mathrm{cf}$ of stormwater runoff. In order to further reduce the runoff from the site, the stormwater plan included the addition of underground infiltration trenches and storage vaults. Those underground structures provide storage for 43,925 cf of stormwater (328,582 gallons), which is $22 \%$ of the total runoff for the design condition. This reduction aids in reducing the university's input into the city's overburdened combined sewer system.

\begin{tabular}{|c|c|c|}
\hline \multicolumn{3}{|l|}{ Infiltration beds } \\
\hline Location & $\begin{array}{l}\text { Storage } \\
\text { (cf) }\end{array}$ & $\begin{array}{l}\text { Storage } \\
\text { (gal) }\end{array}$ \\
\hline East quad & 8700 & 65081 \\
\hline West quad infiltration & 8255 & 61752 \\
\hline Sean Earl Field infiltration & 10470 & 78321 \\
\hline Total: & 27,425 & 205,153 \\
\hline \multicolumn{3}{|l|}{ Storage vault } \\
\hline West quad storage & 16500 & 123428.58 \\
\hline Total: & 16,500 & 123,429 \\
\hline Grand total (Infiltration and Storage vault): & 43,925 & 328,582 \\
\hline
\end{tabular}




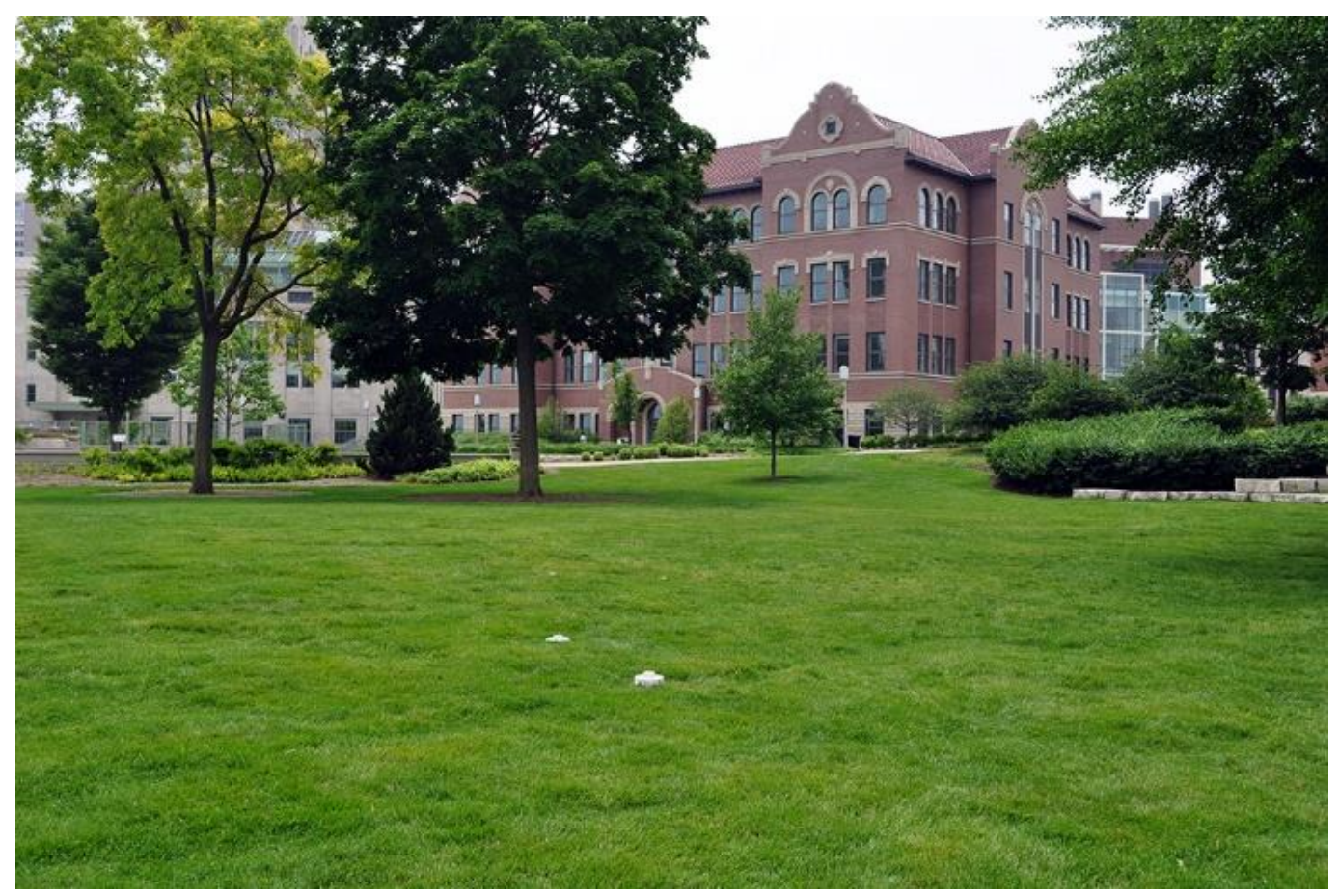

PVC cleanouts are the only clue to the stormwater infiltration area that is hidden below the lawn in the East Quad. Image: Landscape Architecture Foundation (Scott Douglas, CSI 2015)

Sources:

- Data provided by SmithGroupJJR

- City of Chicago CSO event info: http://www.mwrd.org/irj/portal/anonymous/cso

\section{Reduces power consumption by $63,064 \mathrm{kWh}$ and saves $\$ 3,700$ annually by switching to LED lights.}

The university campus features an estimated 163 pole mounted pedestrian light fixtures, which originally used metal halide bulbs. As part of the university's mission to reduce its ecological footprint, the light fixtures were retrofitted with Stenberg Revere series LED fixtures. The LED fixtures consume less than half of the power of the metal halide bulbs, from 94 watts to 200 watts. When these lights are on an estimated average of 10 hours per day, calculations show a savings of $63,064 \mathrm{kWh}$, a reduction of $53 \%$. When multiplied by the current electricity rate of 5.86 cents per $\mathrm{kWh}$, it equals a savings of $\$ 3,695$ per year. The longer life span of LED light sources compared to metal 
halide should provide additional savings over the life of the lights.

\begin{tabular}{|l|c|c|c|c|c|c|c|c|}
\hline & $\begin{array}{c}\text { watts } \\
\text { per } \\
\text { hour }\end{array}$ & $\begin{array}{c}\text { hours } \\
\text { per day }\end{array}$ & $\begin{array}{c}\text { watts } \\
\text { per day }\end{array}$ & $\begin{array}{c}\text { watts } \\
\text { per year }\end{array}$ & $\begin{array}{c}\text { kWh } \\
\text { per } \\
\text { year }\end{array}$ & $\begin{array}{c}\text { number } \\
\text { of lights }\end{array}$ & $\begin{array}{c}\text { total } \\
\text { kWh year }\end{array}$ & $\begin{array}{c}\text { at 5.86 cents } \\
\text { per kWh }\end{array}$ \\
\hline LED & 94 & 10 & 940 & 343,100 & 343.1 & 163 & 55925.3 & $\$ 3,277.22$ \\
\hline $\begin{array}{l}\text { Metal } \\
\text { Halide }\end{array}$ & 200 & 10 & 2000 & 730,000 & 730 & 163 & 118990 & $\$ 6,972.81$ \\
\hline
\end{tabular}

Source:

- Construction documents provided by SmithgroupJJR.

- Light data provided by Sternberg Lighting.

\section{Social:}

\section{Increases awareness of green infrastructure with campus landscape tours that serve $\mathbf{4 0 0 - 8 0 0 ~ v i s i t o r s ~ p e r ~ y e a r . ~}$}

In addition to campus visit tours that the university provides to prospective undergraduate and graduate students, the university also leads tours of the campus landscape and its innovative green infrastructure systems. These tours are held an average of 10-20 times per year and are given to groups that average 40 visitors per tour. These quantities do not include tours that are provided as a part of a special event, such as the tour that was lead as part of Society for College and University Planning (SCUP) International Conference. That tour, which occurred on Saturday July 11, 2015, hosted a group of over 50 American and international campus planners. 


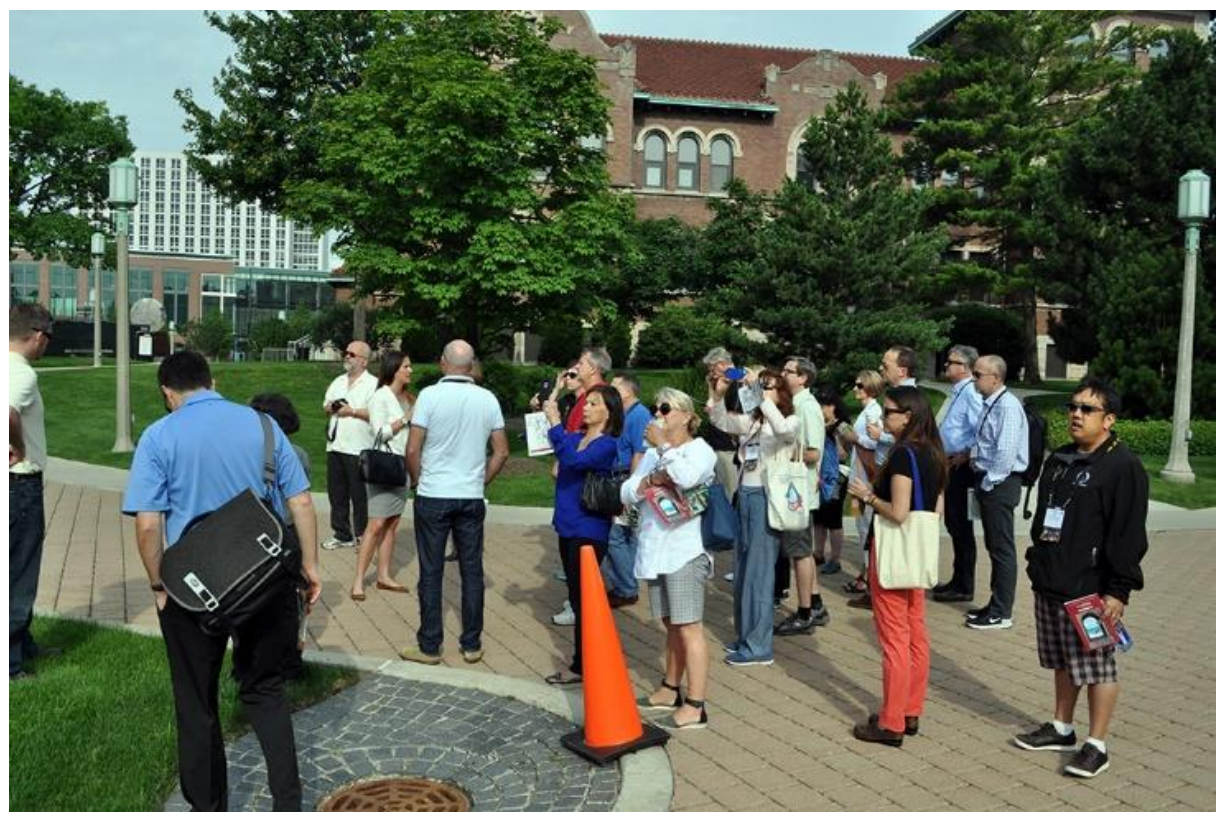

A group of planning professionals from SCUP during a tour of the Loyola University Chicago campus. Image: Landscape Architecture Foundation (Scott Douglas, CSI 2015)

Tours of the Institute of Environmental Sustainability (IES) building, a LEED Gold certified building, are also offered, and they occur an average of 2 times per week. The IES facility building provides space for academic offices, classrooms, research laboratories, and a 410-bed dormitory. This tour covers several important campus features including rainwater harvesting, pervious paving, green roofs, geothermal heating and cooling, biodiesel production, and the integrated greenhouse structure that is referred to as the "Ecodome."

The Ecodome is a 3,100 sf greenhouse that is incorporated into the center of the building and serves as a common space and research laboratory. The research laboratory is utilized by students and faculty for research into food production, aquaponics, and vertical gardening. The aquaponics systems utilize rainwater that is harvested from the building roof and stored in a 3,000 gallon cistern located on the first floor. Water from the cistern is also used for flushing toilets in the restrooms directly adjacent to the storage tank.

In addition to these guided tours, the university provides tour scripts and maps on 
their website for the general public to download and use to create their own self-guided tour. The CSI team was not able to ascertain the number of times that each of these documents has been downloaded from the website as the university did not have a counting function applied to those downloadable files. Informational signage, located throughout the campus, supplements the self-guided tours and provides information to all students and visitors.

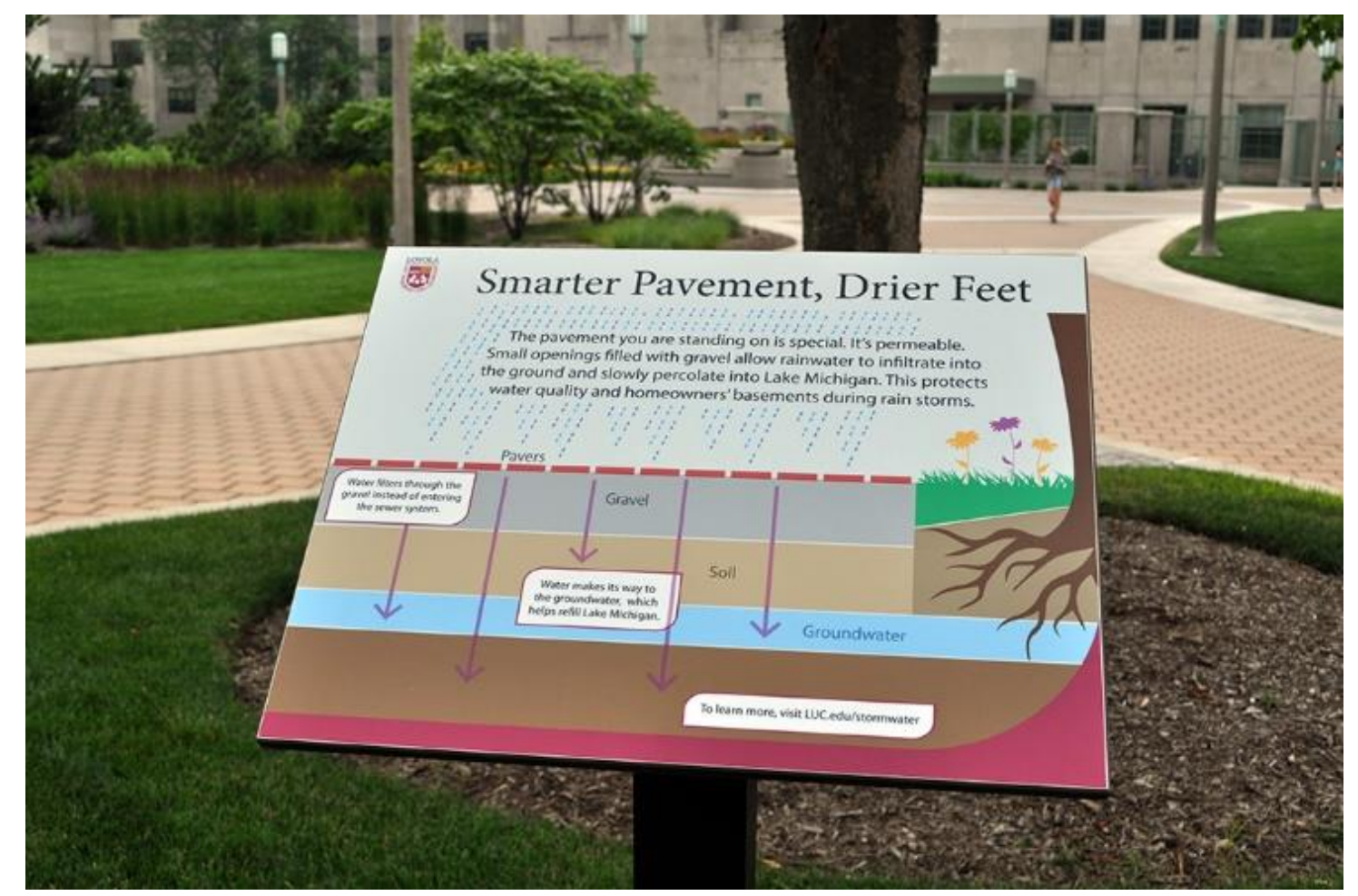

Example of informational signs that provide insight into the ecological systems at work on the campus. Image: Landscape Architecture Foundation (Scott Douglas, CSI 2015) 


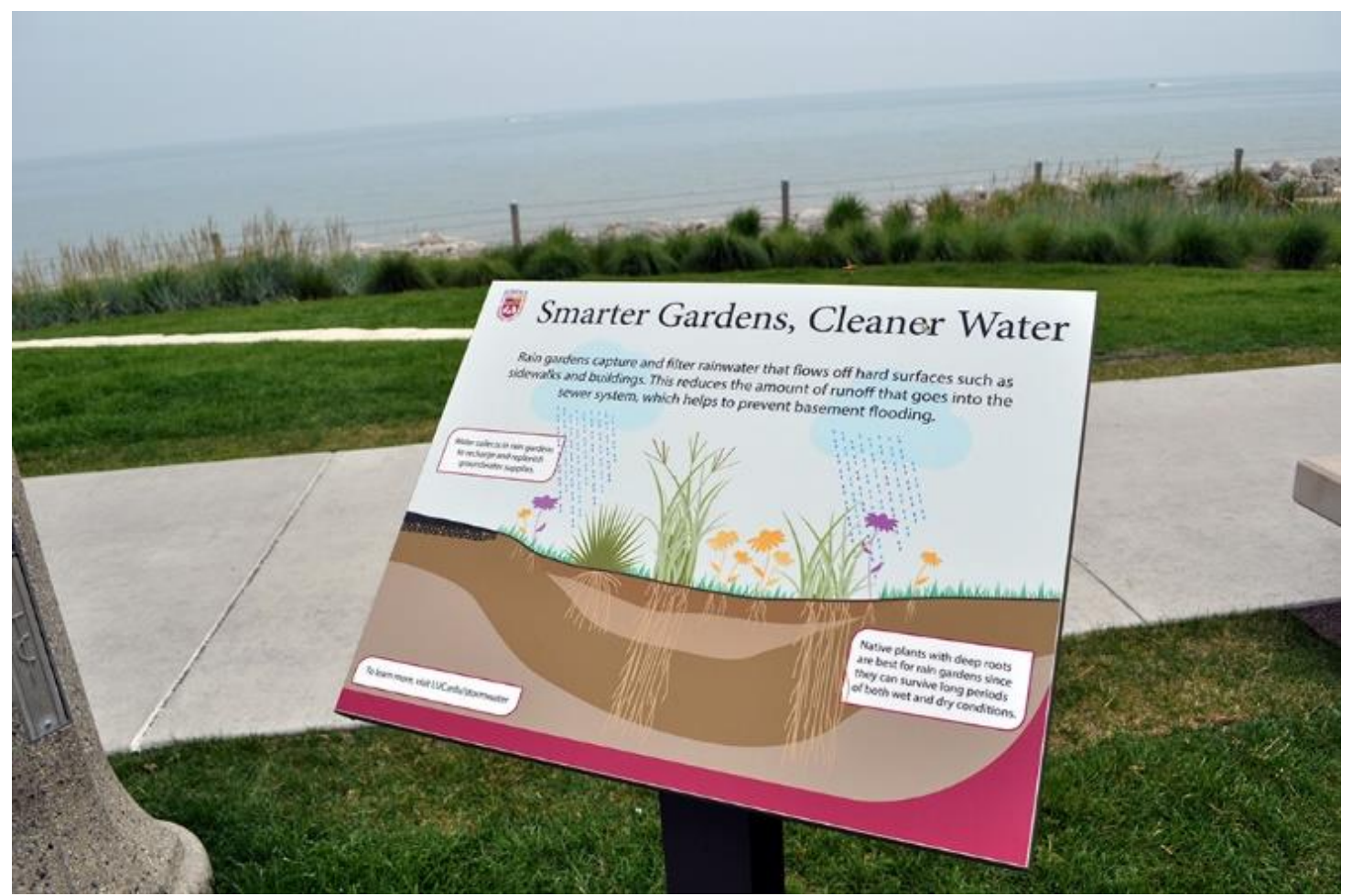

Example of informational signs that provide insight into the ecological systems at work on the campus. Image: Landscape Architecture Foundation (Scott Douglas, CSI 2015)

Sources:

- Data provided by Loyola University Chicago Institute of Environmental Sustainability

- http://www.luc.edu/sustainability/about/ourfacilities/

- http://www.luc.edu/sustainability/resources/quidesfaqs/lsctourresources/\#d.en.24 $\underline{6250}$

- http://www.luc.edu/media/lucedu/sustainabilitynew/pdfs/Institute\%20of\%20Environmental\%20Sustainability\%20Tour\%20Script. $\underline{\text { pdf }}$

\section{Provides land for a community garden with 196 raised beds used by residents from the surrounding neighborhood.}

The university has leased a 17,182 sf (0.39 acre) lot at the corner of North Broadway and W. Rosemont Avenue to the Peterson Garden Project, a community gardening 
group. The group has constructed 196 raised planting beds $(4 \mathrm{ft} \times 8 \mathrm{ft}$ ) on the site along with tool storage areas and a water basin. The group provides each participant with one $4 \mathrm{ft} \times 8 \mathrm{ft}$ garden plot and teaches the participants how to grow their own vegetables. The community garden group provides the land, water, tools, and knowledge, and the participants provide the seeds/plants and sweat equity. The ultimate goal of the group is to create long-term gardeners who can successfully grow their own food. This group is the gardening version of the old saying, "give a man a fish and you feed him for a day, teach a man to fish and you feed him for a lifetime."

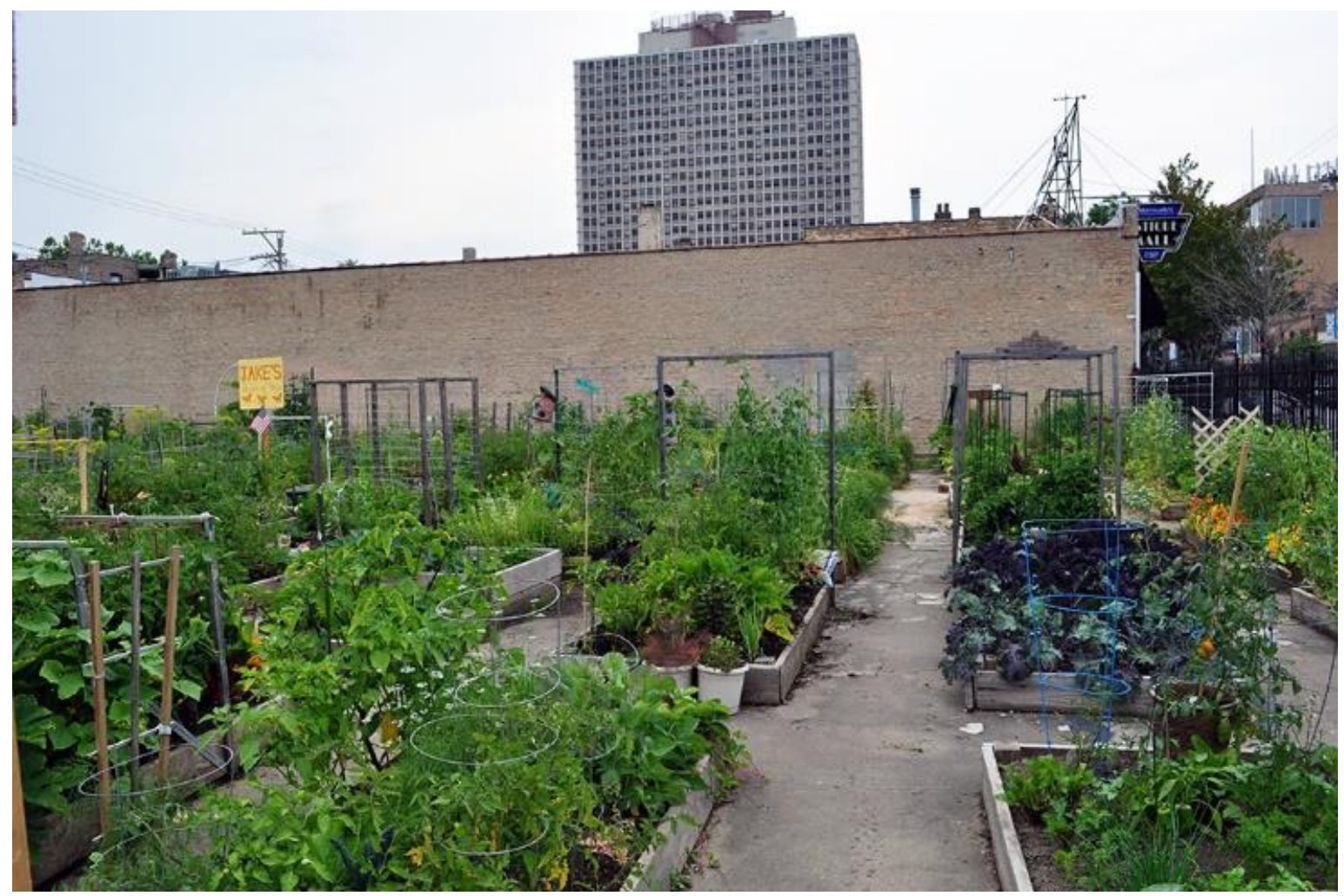

Community garden that is located on property that is owned by the university. Image: Landscape Architecture Foundation (Scott Douglas, CSI 2015)

Perhaps more important than the crops that are raised in the gardens, these community gardens foster relationships between a variety of residents from different backgrounds and cultures who might not have interacted with each other in their everyday lives. The group encourages community members from a wide variety of 
cultures who have strong cooking skills to volunteer to teach cooking classes for other members in order to introduce them to their culture's cuisine. This helps to raise awareness of the other cultures that live in the surrounding neighborhood.

Sources:

- Data provided by Loyola University Chicago

- Peterson Garden Project website: http://petersongarden.org/

\section{Hosts over 50 outdoor events annually.}

When the campus's original east lawn was overused due to its popularity with students and its use for outdoor events, the turf grass suffered immensely. When the university decided to create a new outdoor space in the west quad, it was imperative that the turf area could handle heavy usage.

In order to mitigate the anticipated heavy usage, the new central lawn area in the west quad was specifically designed as if it was an athletic field. The subbase under the lawn area consists of a 6" compacted sand base for support and drainage that is topped with a 6" layer of topsoil on which the Kentucky Bluegrass sod was laid.

While most sports fields would have a network of underdrains to evacuate water from the subbase, the native sandy soils in the area allow for percolation of water and eliminated the need for a network of underdrains beneath the field. In order to support drainage during major rain events, the field surface is crowned at the middle and slopes down to the outside edges. A perforated drain pipe was installed around the perimeter of the field at the base of the low wall that encloses the turf area to provide supplementary drainage during heavy rain events. 


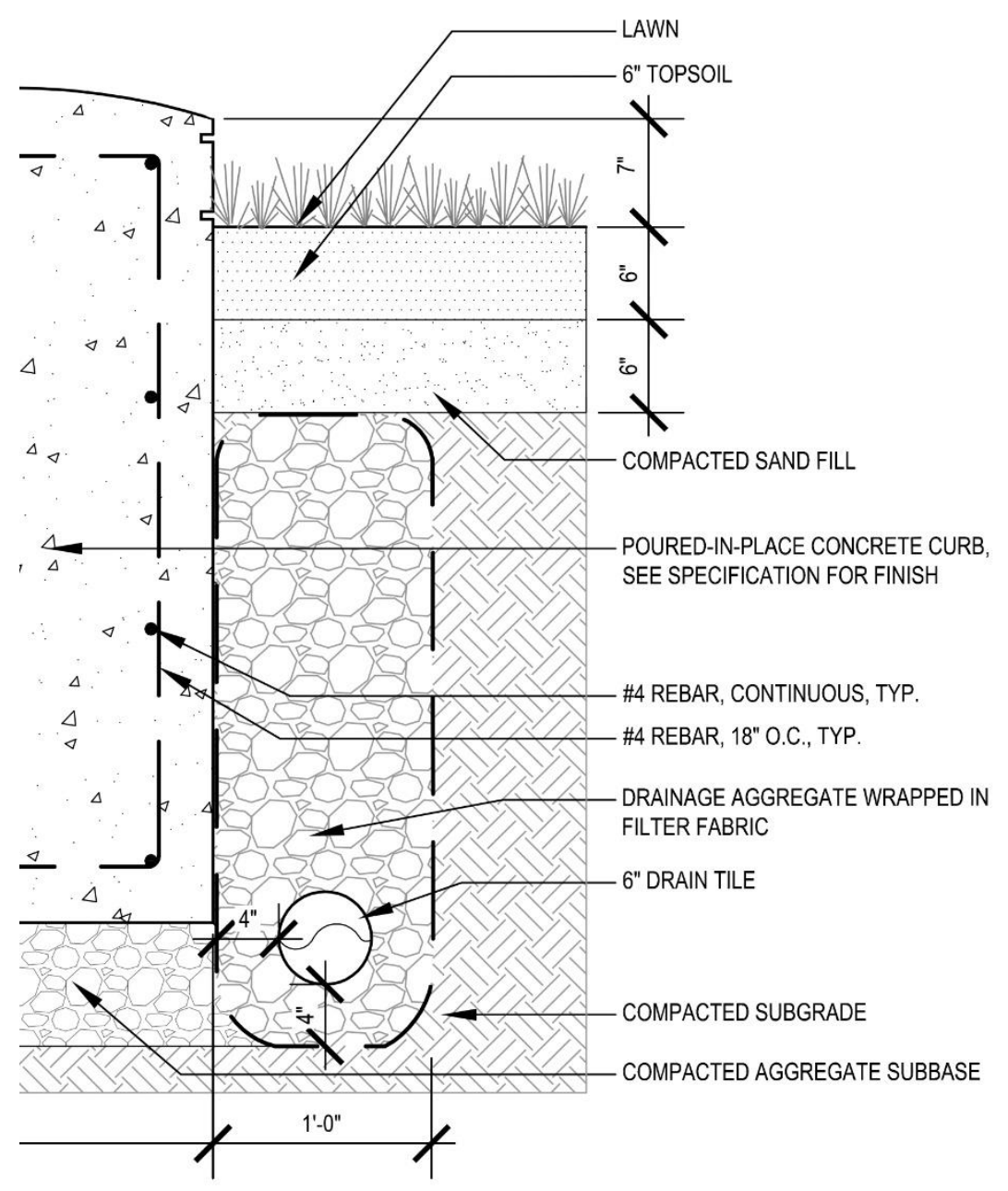

Construction section of the west quad turf area and perimeter drain. Image: SmithGroupJJR.

This area supported 14 major events in 2014. In addition to these organized events, the lawn is heavily used by students for various personal and small group activities. While the CSI team was on campus, several groups of students were seen utilizing the space to throw footballs and frisbees while others were using the space to do workout routines.

In addition to the west quad area, several other outdoor campus spaces also support events. Those spaces include the chapel garden and the east quad, which both host large picnics and wedding receptions on their turf areas. The Loyola Plaza, which is located adjacent to the Chicago Transit Authority's Red Line Train Station, hosts a 
weekly farmers market on Mondays from early June through mid-October.

Sources:

- Data provided by Loyola University Chicago IES Urban Agriculture Coordinator

- Data provided by SmithGroupJJR

\section{Produces over $2,500 \mathrm{lbs}$ of produce and $\$ 4,000$ in revenue on less than $1 / 3$ of an acre through a student-run, on-campus urban gardening program. $20 \%$ of the produce raised is donated to local food banks.}

As part of Loyola's Urban Agriculture Program, a team of 14 student employees and 300 student volunteers managed multiple on-campus garden spaces to grow and harvest over 2500 pounds of produce in 2014 (This project is separate from the Peterson Garden discussed elsewhere in this report). This produce was sold in the student-run Loyola Farmers Market hosted at the Loyola Plaza adjacent to the CTA station, generating $\$ 4,000$ in revenue. This connection with the CTA station allows the farmers market to access a wider range of the general public and expands the radius of their outreach. $500 \mathrm{lbs}(20 \%)$ of the produce raised were donated to local food banks in 2014.

The farmers market was created by a team of students that participated in the university's Solutions to Environmental Problems (STEP) Food Systems course. The market was established to improve the community's access to fresh, affordable, locally grown produce and to support other small local farmers, bakers, yogurt/ice cream makers, and other small businesses. The farmers market is also certified to accept the Supplemental Nutrition Assistance Program (SNAP) Illinois Link card. The farmers market runs every Monday from early June through mid-October.

The garden spaces used for this production include:

- The Victory Garden is located on the Mertz Dormitory Terrace and features 15 raised beds.

- Quinlan Rooftop Garden is located on the roof of the Quinlan Life Science building and features 11 raised beds and 6 large pots. 
- Winthrop Garden is a ground-level garden that features 30 raised beds and 2 beehives. The beehives, another product of the STEP course, provide habitat for the pollinators required for successful gardening.

- Greenhouse Lab in the Institute of Environmental Sustainability building features 3,100 sf of growing space and 2 aquaponics systems.

The combined area of these garden spaces is approximately $1 / 3$ of an acre. All revenue generated by the sale of produce is reinvested into the Urban Agriculture program to fund the purchase of any needed supplies, materials, or seeds.

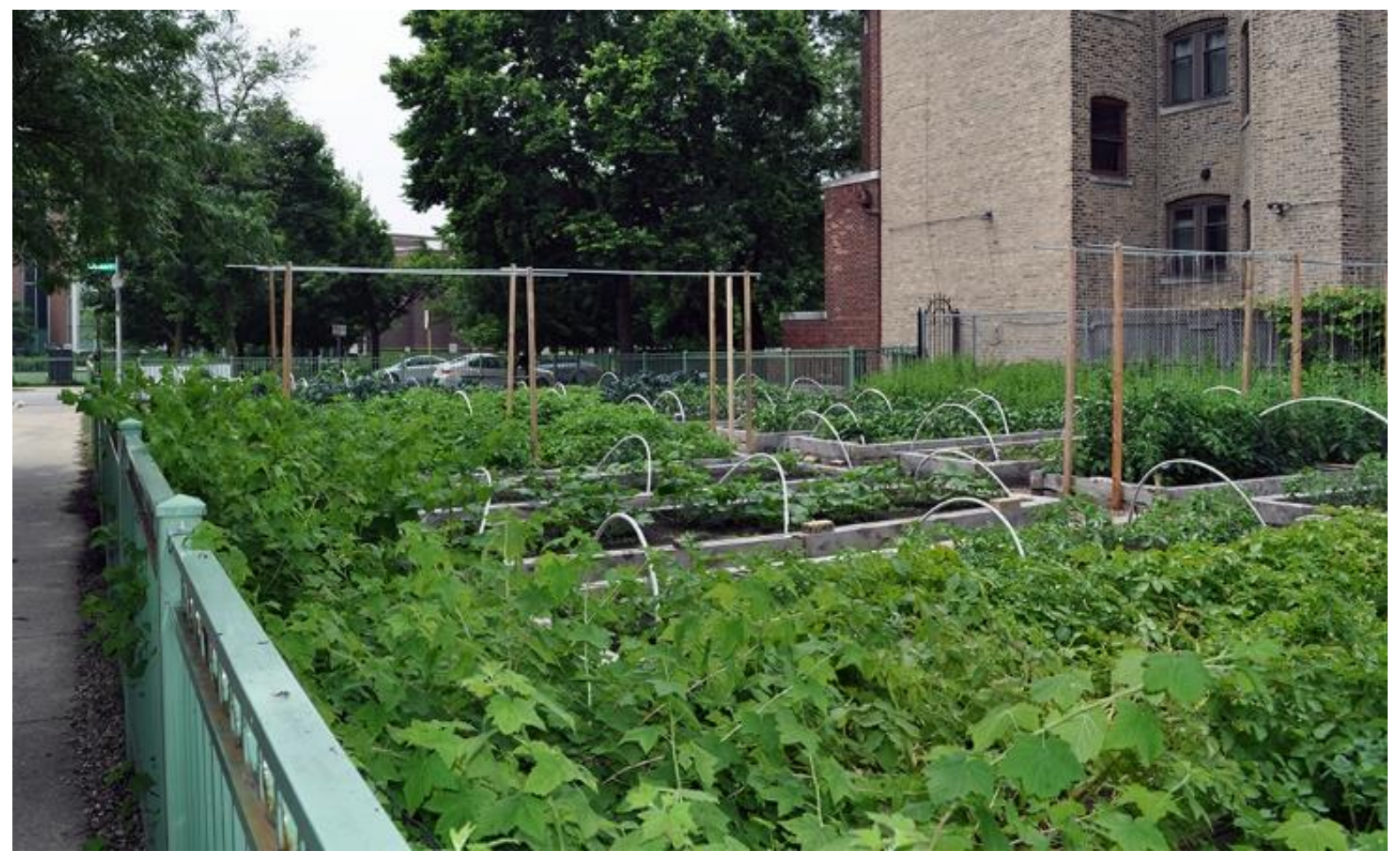

The Winthrop Garden provides space for student gardeners to raise vegetables for sale at the farmers market and for donation to local food banks. Image: Landscape Architecture Foundation (Scott Douglas, CSI 2015)

Sources:

- Data provided by Loyola University Chicago IES Urban Agriculture Coordinator

- http://blogs.luc.edu/farmersmarket/

- http://www.luc.edu/sustainability/initiatives/urban-agriculture/sustainablefood/ 


\section{Economic:}

\section{Saved over $\$ 182,000$ through reutilization of existing light poles.}

During the renovation of the campus spaces, the design team was able to salvage and reuse the existing concrete light poles. The reuse of the $12 \mathrm{ft}$ cast concrete poles with integrated GFI plugs resulted in a significant cost savings. Approximately 91 light fixtures were reused, saving an estimated $\$ 2,000$ per pole. That results in a total savings of over $\$ 182,000$. The reused poles were topped with LED light fixtures as discussed in the Environmental Benefits section.

\section{Influenced decision to enroll for $\mathbf{8 2 . 6 \%}$ of $\mathbf{4 3 1}$ incoming freshmen, who selected the 'attractive campus' as the second most important factor in their decision to enroll at the University.}

While there has been a strong focus on making a functional and environmentally friendly campus, the campus design has also increased the visual quality and beauty of the Loyola campus. When the 431 incoming freshmen for the fall of 2015 were asked for their top reasons for attending Loyola, "attractive campus" was the second highest response at $82.6 \%$. It only followed "location," which was selected by $90.7 \%$ of the students. Attractive campus came in above "Loyola offers my intended major" and "academic reputation is strong" among other possible responses.

When those same 431 incoming were asked "How important was Loyola's commitment to sustainability/sustainability programming in your decision to attend Loyola University Chicago," $48.5 \%$ responded "important" or "very important." Only $8.35 \%$ responded "unimportant" or "very unimportant." While that leaves $43.15 \%$ of the students as undecided on the issue, the vast difference between those who feel it is important versus those who do not is significant. These survey results show that the university's commitment to sustainability and the beautiful campus that they have created is having a positive impact on the decision of students to attend the university. 


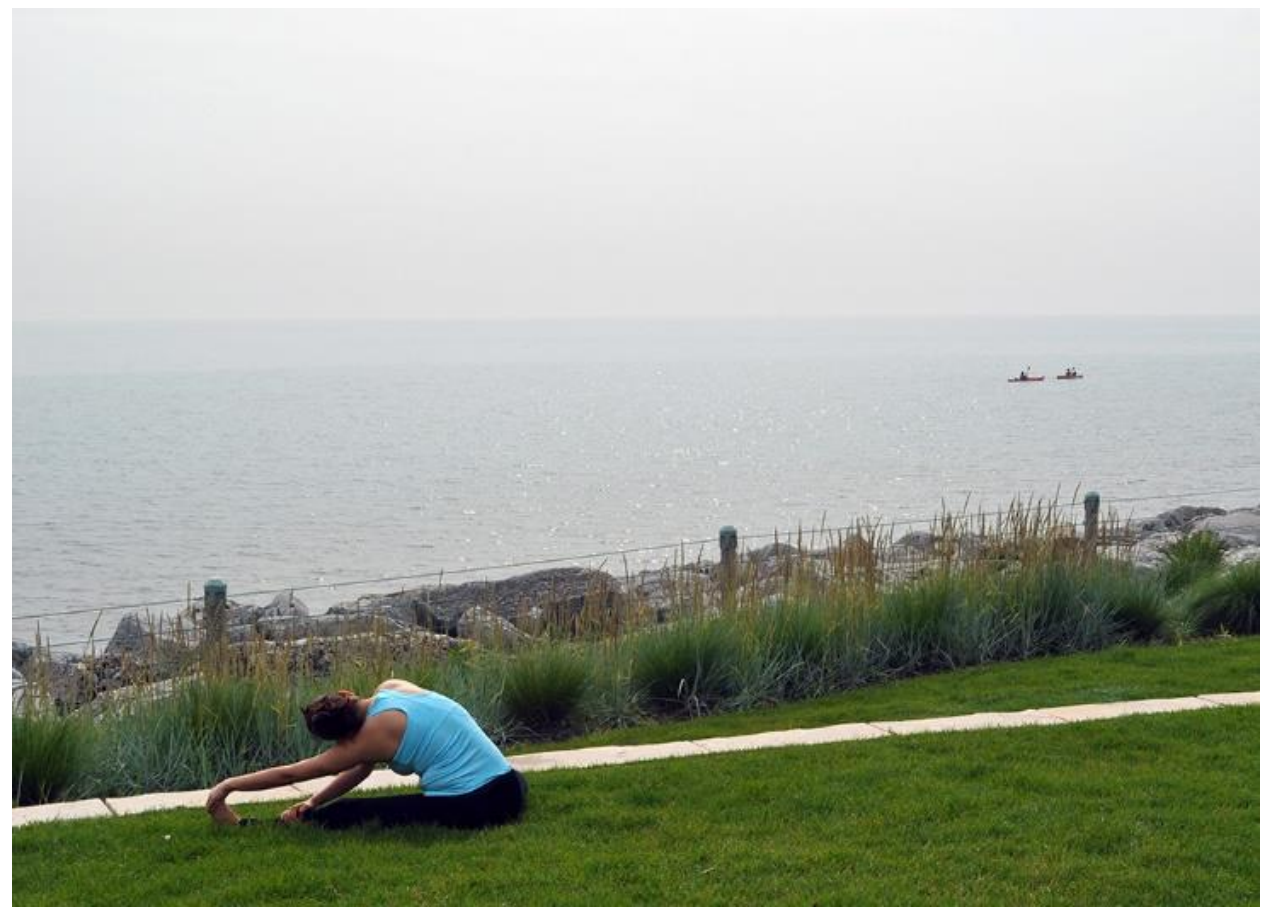

The campus features views of Lake Michigan and ample green space for students to stretch out and relax. Image: Landscape Architecture Foundation (Scott Douglas, CSI 2015)

\section{Sources:}

- 2015 Intent to Enroll Survey Tables produced by ESRR and provided by Loyola University Chicago.

\section{Cost Comparison}

When working to find stormwater containment systems that could effectively contain the 0.5 in first flush of stormwater for the campus, the design team evaluated underground concrete storage cell systems and aggregate based infiltration beds. Aggregate infiltration beds can range in price from $\$ 10-\$ 30$ per cu ft while concrete chambers range in price from $\$ 8-\$ 15$ per cu ft of storage.

While the aggregate systems have a higher cost, they come with the benefit of allowing captured stormwater to infiltrate down into the subsoil. Since the Loyola campus is located on top of fast-draining sandy soils, the infiltration beds had a distinct advantage of providing an opportunity for the water to drain out of the bed, unlike the 
solid concrete cells which would have to discharge to the combined sewer system at some point. Because of this infiltration advantage, the team elected to use infiltration beds in any location where the soil tests confirmed adequate percolation into the soil.

The design team also evaluated cost comparisons of permeable pavers versus concrete for the pedestrian walkways. Permeable paver installations range from $\$ 10$ $\$ 15$ per sf (including the aggregate base), compared with concrete with ranges from \$6$\$ 7$ for a vehicular-rated thickness. Since these walkways also serve as service drives and emergency access, the sidewalks had to be able to withstand vehicular loads.

\begin{tabular}{|l|l|l|l|l|}
\hline & \multicolumn{2}{|c|}{ Low } & \multicolumn{2}{c|}{ High } \\
\hline & per sf & 80,000 sf & per sf & 80,000 sf \\
\hline Permeable pavers & $\$ 10.00$ & $\$ 800,000.00$ & $\$ 15.00$ & $\$ 1,200,000.00$ \\
\hline Concrete sidewalk & $\$ 6.00$ & $\$ 480,000.00$ & $\$ 7.00$ & $\$ 560,000.00$ \\
\hline & Difference: & $\mathbf{\$ 3 2 0 , 0 0 0 . 0 0}$ & & $\$ 640,000.00$ \\
\hline
\end{tabular}

While the permeable pavers have a higher installation cost, that cost is offset by the porosity of the surface, which reduced stormwater runoff and the amount of required stormwater storage. It also continues the advantage of allowing infiltration of stormwater into the sandy subsoils.

\section{Additional information}

\section{Replaced over 195,686 sf of impervious surface parking lots and roadways with $\mathbf{8 0 , 0 0 0}$ sf of permeable sidewalks and green space, reducing runoff and creating a pedestrian friendly campus core.}

In an effort to remove impervious paving and vehicular parking areas from the interior of the campus, the university has removed 195,686 sf (4.49 acres) of impervious paving from the campus. While the original campus layout allowed for vehicular travel through the middle of the campus, vehicles are now relegated to the perimeter of the campus. In order to provide on-site parking for faculty and staff members, 2 parking decks were constructed to provide parking after the removal of the surface parking lots.

More importantly, the removal of this paving transformed the campus into a pedestrian-oriented facility. A network of 80,000 sf of permeable pedestrian sidewalks 
have replaced the roadways and several of the parking lots were converted into green spaces, including the Chapel Garden, Sean Earl Field, and a courtyard between the Mundelein Center, Coffey Hall and Piper hall. These changes have reduced runoff, which reduces the need for stormwater management systems and increased the infiltration of water into the ground.

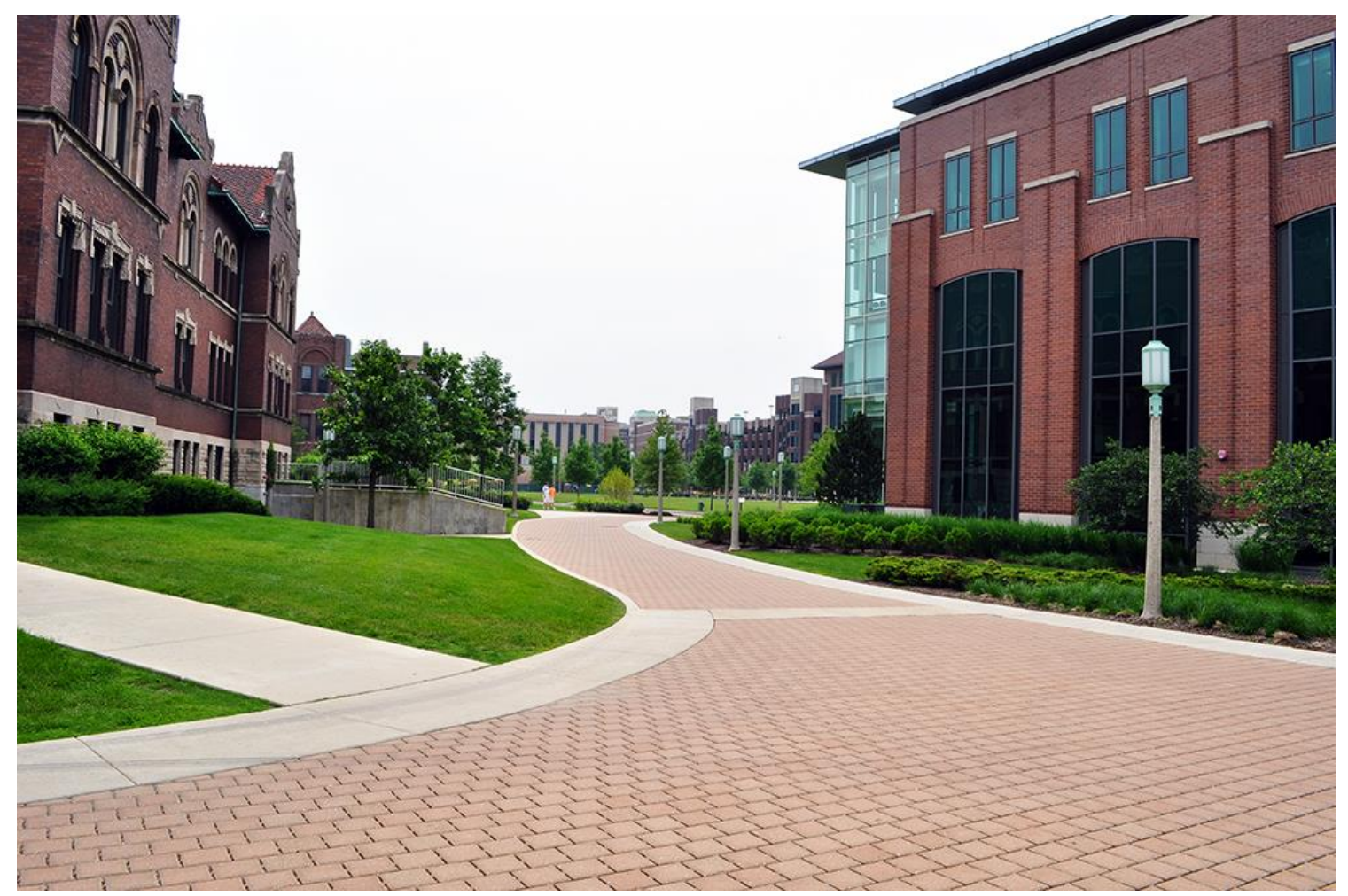

Example of a pedestrian area that was formerly a paved road used to access parking lots that were located in the campus interior. Image: Landscape Architecture Foundation (Scott Douglas, CSI 2015) 


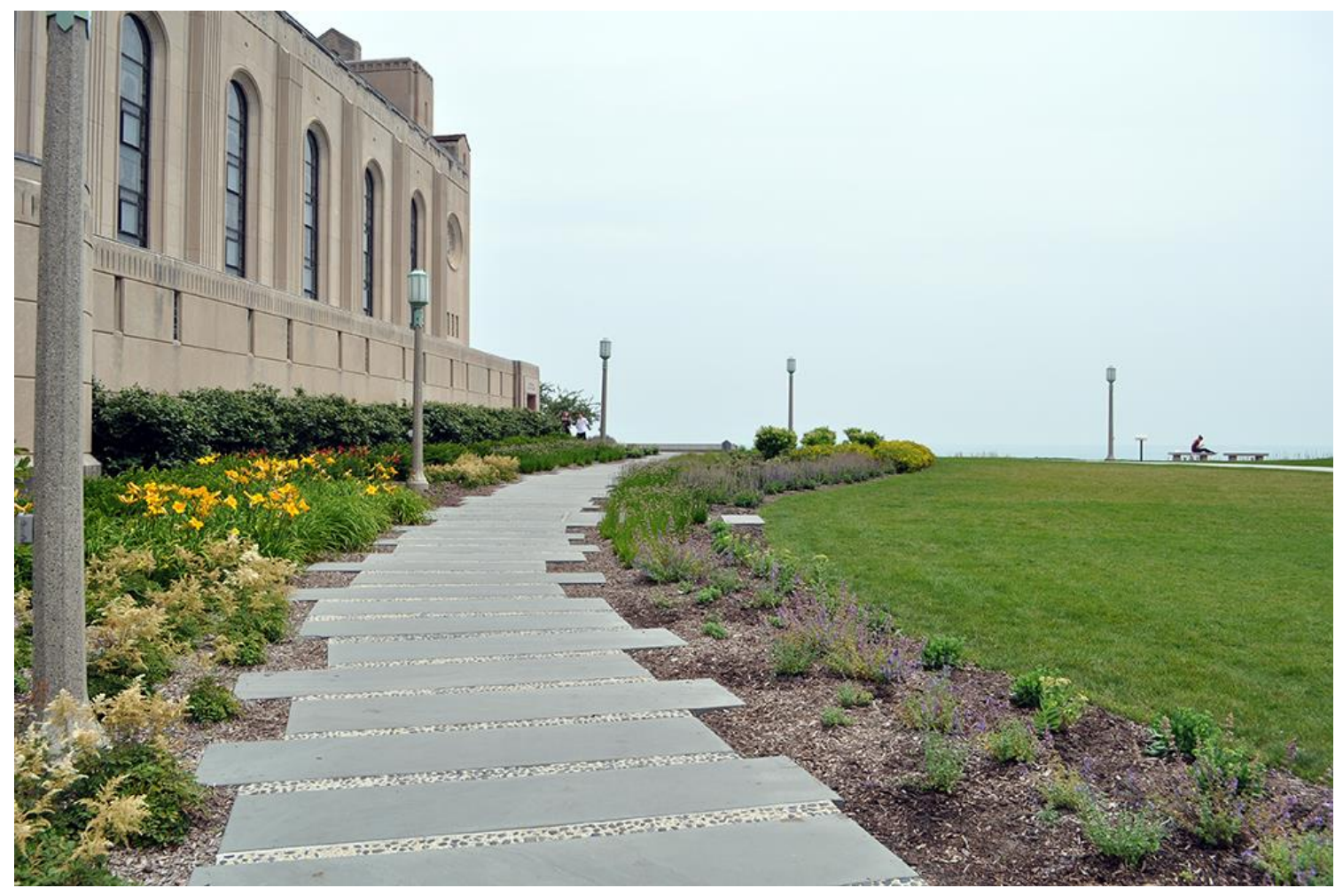

Example of a pedestrian area that was formerly a paved parking lot. Image: Landscape Architecture Foundation (Scott Douglas, CSI 2015)

\section{Source:}

- Data provided by SmithGroupJJR

Incorporated 24 species of native plants into the campus landscape, an increase of $90 \%$ prior to the landscape architect's involvement.

The university campus is situated on native sandy soils that drain rapidly, requiring particular attention when selecting plants for the campus landscape. The landscape architects selected a variety of native plant species that are deep-rooted and well adapted to the sandy soil condition. These additional native plant species increased the native plant species diversity on campus by $90 \%$.

The native plants that were installed on the campus include: 


\begin{tabular}{|c|c|}
\hline SCIENTIFIC NAME & COMMON NAME \\
\hline \multicolumn{2}{|l|}{ SHADE TREES } \\
\hline Acer rubrum 'Red Sunset' & Red Sunset Red Maple \\
\hline Acer rubrum 'Redpointe' & Redpointe Maple \\
\hline Acer saccharum 'Morton' & Sugar Maple \\
\hline Celtis occidentalis 'Prairie Pride' & Prairie Hackberry \\
\hline Quercus bicolor & Swamp White Oak \\
\hline Quercus rubra & Red Oak \\
\hline Tilia americana & American Linden \\
\hline \multicolumn{2}{|l|}{ ORNAMENTAL TREES } \\
\hline Amelanchier x grandiflora 'Princess Diana' & Princess Diana Serviceberry \\
\hline Cercis candensis & Eastern Redbud \\
\hline \multicolumn{2}{|l|}{ DECIDUOUS SHRUBS } \\
\hline Cornus sericea 'Isanti' & Isanti Redtwig Dogwood \\
\hline Cornus sericea 'Bergensons' & Red osier Dogwood \\
\hline Physocarpus opulifolius 'Diablo' & Ninebark \\
\hline Viburnum prunifolium & Blackhaw Viburnum \\
\hline \multicolumn{2}{|l|}{ PERENNIALS } \\
\hline Bouteloua curtipendula & Side Oats Gramma \\
\hline Echinacea purpurea 'Kim's Knee High' & Kim's Knee High Purple Coneflower \\
\hline Mertensia virginica & Virginia Bluebells \\
\hline Osmunda cinnamomea & Cinnamon Fern \\
\hline Panicum virgatum 'Northwind' & Northwind Switch Grass \\
\hline Rudbeckia speciosa 'Viette's Little Suzy' & Black-Eyed Susan \\
\hline Rudbeckia 'Little Gold Star' & Little Gold Star Black-Eyed Susan \\
\hline Sporobolus heterolepsis & Prairie Dropseed \\
\hline Schizachyrium scoparium 'Carousel' & Little Bluestem \\
\hline Solidago nemoralis & Old Field Goldenrod \\
\hline Sorghastrum nutans & Indiangrass \\
\hline
\end{tabular}


The city of Chicago is located along a major north/south migratory bird route. A student group, Student Operation for Avian Relief (SOAR), is documenting the variety of birds that are found on the campus. In the fall of 2013, this group identified 21 migratory bird species and that quantity increased to 36 in the fall of 2014. That is an increase of $71.43 \%$ in migratory bird species over a 1-year period. Additional research would be necessary to verify a direct relationship between the increase in native plant species and the increase in migratory bird species.

The SOAR group is actively working on campus to document migratory bird strikes into buildings and is working with officials to make the campus buildings more bird-friendly. While the large expanses of glass on some of the new buildings frame beautiful views of the lake for the students and staff, they also create a hazard for migratory birds that cannot see the glass. The SOAR group has identified appropriate solutions for several buildings, including the closing of blinds during the morning hours so the birds can see the blinds and avoid the buildings.

Source:

- Plant lists and construction documents provided by SmithGroupJJR.

- http://www.luc.edu/sustainability/initiatives/biodiversity/studentoperationforavianr eliefsoar/migratorybirdspecies/

- http://www.luc.edu/sustainability/initiatives/biodiversity/studentoperationforavianr eliefsoar/buildingsofconcern/

\section{Generated over $\$ 47,500$ in product through student-run on-campus business enterprises.}

The university's green initiative has led to the creation of the Solutions To Environmental Problems (STEP) courses at the Institute of Environmental Sustainability. Those classes have led to the creation of numerous student-run businesses that are producing revenue and providing green products to the community.

The student-run biodiesel production system has transformed into a student-run business that is certified to sell biodiesel. This enterprise has been certified as a green 
business by the Illinois Green Business Association and is the only on-campus production facility in the United States that is licensed to sell biodiesel. The biodiesel is also used to power a supplemental boiler in the IES building during periods of extremely cold weather.

Biodiesel sale price: $\$ 4.00$ per gallon

2014-2015 school year production: 2,500 gallons

$\$ 10,000.00$ value

In an attempt to fully utilize the by-products of the biodiesel production, the students have been researching options for repurposing them. They are now processing glycerin, one of the by-products from the biodiesel process, to produce soap. What started out as bar soap has evolved into a liquid soap product named BioSoap. Not only is the BioSoap available for sale to the general public, but the soap is now being utilized in all of the restrooms on the entire campus.

BioSoap sale prices: $\$ 2$ - Sample (2 oz), \$5 - Dispenser (8 oz), \$15 - Refill (1 gal) 2014-2015 school year production: 2,500 gallons

The exact sales distribution (sample, dispenser, and refill) data was not available. Estimated value at the low end ( 1 gallon refill) equals a minimum value of $\$ 37,500$.

The program is continuing to expand its production and product offerings. They are beginning to offer bug repelling Tiki torch fuel and are in the process of finalizing their formula for windshield washer fluid. The Tiki torch fuel will retail for $\$ 9.99$ for a 32oz bottle, pricing has not been set for the windshield washer fluid. Projected production for the 2015-2016 school year:

- Biodiesel-9,500 gallons

- BioSoap - 1,500 gallons

- Windshield Wiper Fluid - 500 gallons

- Tiki torch fuel - not available 
The revenue generated from the sale of these products provide the day-to-day operating funds necessary to pay for supplies, maintenance, student staff pay, research supplies, analytic consumables, product development, and outreach. This program does not have an associated university budget allocation to cover those costs.

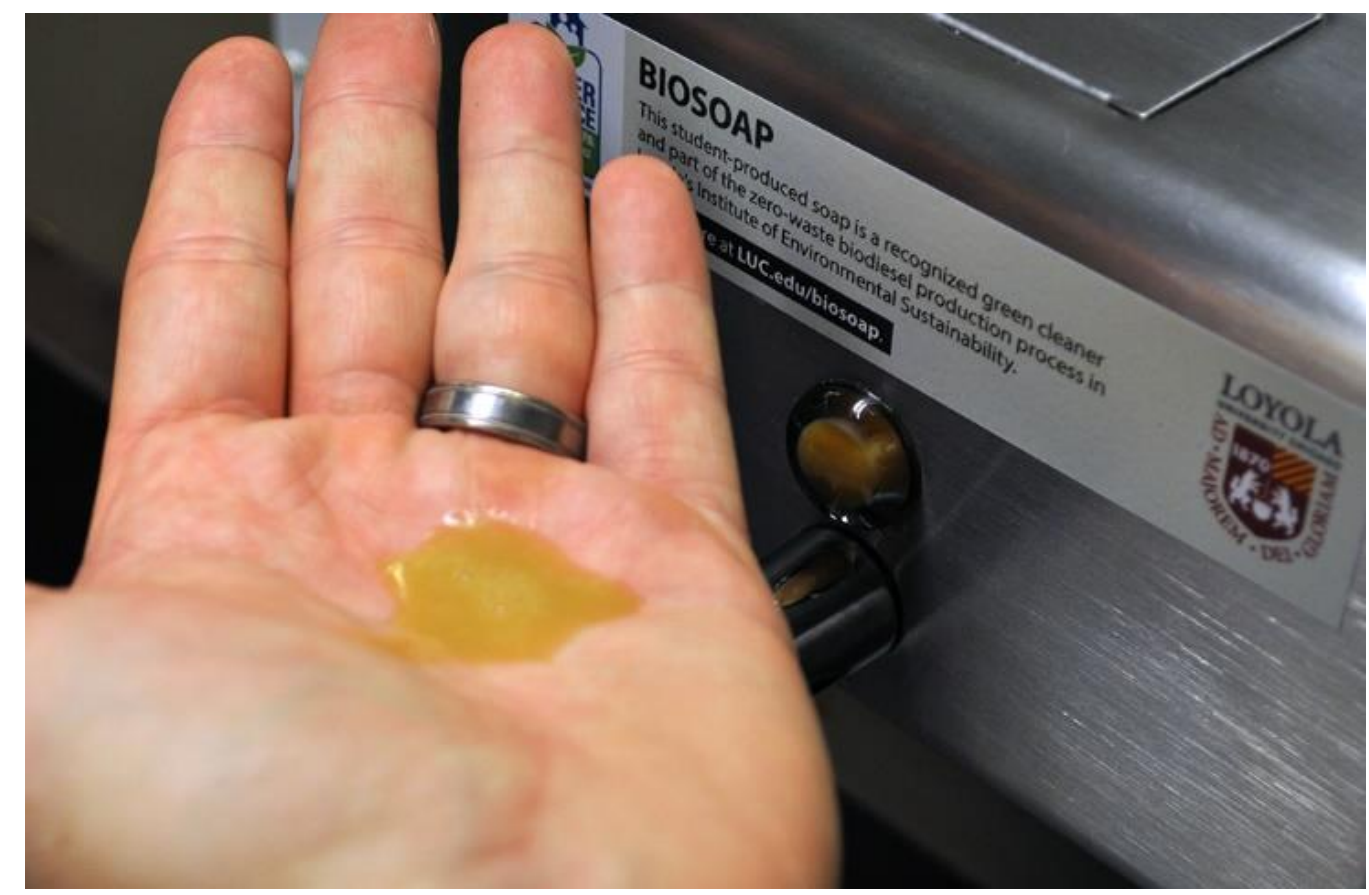

BioSoap, created from by-products of the biodiesel production and used in all restrooms on campus. Image: Landscape Architecture Foundation (Scott Douglas, CSI 2015)

Sources:

- Data provided by Loyola University Chicago

- http://www.luc.edu/sustainability/initiatives/biodiesel/products/

\section{Construction Cost Indexes}

During design and construction, every project on the Loyola campus went through some variation of scope development/modification between budgets, plus a few rounds of value engineering or alternate pricing to accommodate the university's desire for choices and change. The combination of being a private university plus the fact that they were working with the same design and construction team on each project made it a very fluid process. Cost savings due to reduced prices could be easily rolled back into 
the projects through additions and changes. Unfortunately, the large quantity of modifications made it unrealistic to acquire cost estimate data and actual cost data that were truly comparable. While the CSI team did not have first-hand data from the university's projects, the team did analyze two major construction cost indexes to identify the potential savings that could be gained during the economic downturn. The team evaluated the Rider Levett Bucknall (RLB) USA Report and the Turner Building Cost Index for the time period between the end of the 2nd quarter in 2008 to the end of the 3rd quarter in 2011. Both indexes showed a drop during the time frame in question, with the RLB index dropping $7.95 \%$ and the Turner index dropping $13.17 \%$. Averaging the two index drops resulted in an average drop of $10.6 \%$. Based on that average drop in construction values, the team created a chart to demonstrate potential cost savings during the drop in construction costs. When applied to multi-million dollar projects, the savings at $10.6 \%$ quickly become substantial. 